\title{
Trends in determinanten van perinatale sterfte in Nederland
}

\author{
K.M. van der Pal-de Bruin, ${ }^{1}$ A.D. Mohangoo, ${ }^{1}$ P.W. Achterberg, ${ }^{2}$ S.E. Buitendijk ${ }^{3}$
}

\begin{abstract}
Perinatale sterfte is een belangrijke indicator van de kwaliteit van de verloskundige zorg. Er zijn een groot aantal, interacterende, determinanten die de trend in perinatale sterfte beïnvloeden. Het betreft een samenspel van kenmerken van moeder (zoals medische geschiedenis, leefstijlfactoren, leefomstandigheden) en kind (vroeggeboorte, laag geboortegewicht, aangeboren afwijkingen) en kenmerken gerelateerd aan de organisatie van de verloskundige zorg. In Nederland is de perinatale sterfte de afgelopen jaren verder gedaald. Dat wil niet zeggen dat alle determinanten die van invloed zijn op de perinatale sterfte ook een gunstige ontwikkeling laten zien. Determinanten die bijdragen aan het verminderen van de perinatale sterfte zijn onder andere betere overlevingskansen bij vroeg geborenen tussen 28-36 weken zwangerschap door ontwikkelingen in de zorg en een lager aantal rokende vrouwen tijdens de zwangerschap. Ongunstige ontwikkelingen zijn de toename van obesitas bij vrouwen, het nog licht toenemend antal zwangerschappen bij vrouwen van 35 jaar of ouder en bij niet-westerse allochtone vrouwen. Gezien de relatie tussen leefstijlfactoren, niet-optimale leefomstandigheden en ongunstige zwangerschapsuitkomsten is het belangrijk dat, naast medisch ingestoken oplossingen en integrale zorg, ook middels preventie voorafgaand aan en tijdens de zwangerschap de gezondheid van toekomstige ouders en pasgeborenen wordt bevorderd.
\end{abstract}

Trefwoorden: trend, determinanten, perinatale sterfte, preventie

\section{INLEIDING}

Perinatale sterfte is een belangrijke indicator van de kwaliteit van verloskundige zorg. ${ }^{1}$ Nederland kent verassend genoeg een relatief hoog perinataal sterftecijfer. Dat bleek opnieuw uit de resultaten van het grootschalig onderzoek Euro-Peristat gebaseerd op het registratiejaar $2004 .^{2}$ In het jaar 2000 had Nederland vergeleken met veertien andere West-Europese lidstaten, gerekend vanaf 22 weken zwangerschap het hoogste perinatale sterftecijfer (10,9 per 1000 geborenen versus $5,7-10,5 \%)$. ${ }^{3}$ Vier jaar later had Nederland met een perinataal sterftecijfer van $10,0 \%$ nog steeds een ongunstige positie in de Europese rangorde, ditmaal vergeleken met 25 andere landen. ${ }^{4}$

Naast registratieverschillen tussen landen zoals compleetheid van registraties, verschillen in inclusiecriteria en het al dan niet meerekenen van zwangerschapsafbrekingen in foetale sterftestatistieken spelen ook verschillen tussen landen in achterliggende risico's, zoals risico's gerelateerd aan maternale kenmerken, en verloskundige zorg een rol bij de internationale variatie in sterftecijfers.

\footnotetext{
${ }^{1}$ TNO, Leiden

${ }^{2}$ RIVM, Bilthoven

${ }^{3}$ Universiteit Leiden, Leiden
}

Een voorbeeld hiervan is dat in Nederland in die periode geen of nauwelijks screening op aangeboren afwijkingen plaatsvond. Hierdoor overleden baby's met ernstige aangeboren afwijkingen relatief vaker in de perinatale periode. $^{5}$

Net als in andere Europese landen daalt in Nederland de perinatale sterfte (Figuur 1). In de jaren negentig bleek deze daling in Nederland minder sterk te zijn dan in andere landen. ${ }^{6}$ De Stichting Perinatale Registratie Nederland registreerde in 2008 het laagste sterftecijfer bij geboortes vanaf 22 weken zwangerschap, namelijk 9,2\%o. Vergeleken met de jaren $2000(11,4 \%)$ en $2004(10,0 \%$ o) is de sterfte afgenomen met respectievelijk $19 \%$ en $13 \%$. Ook het Centraal Bureau voor Statistiek rapporteert een vergelijkbare afnemende trend vanaf 24 (9,1\%o-7,8\%o$6,3 \%$ ) en 28 ( $7,8 \%$ - $6,6 \%$ - $5,4 \%$ ) weken, zoals weergeven in Figuur 1. In 2009 is het sterftecijfer vanaf 24 en 28 weken verder gedaald naar respectievelijk $5,7 \%$ on $4,8 \%$ o en lijkt zich te stabiliseren in 2010.

In 2004 vond $70 \%$ van de perinatale sterfte plaats vóór of tijdens de bevalling (foetale sterfte 7,0\% en vroeg neonatale sterfte $3,0 \%$ ). In 2008 was de foetale sterfte afgenomen met $0,5 \%$, terwijl de vroeg neonatale sterfte nagenoeg gelijk bleef (van 3,0\%o naar 2,9\%o). Bij internationale vergelijking van sterfte vanaf 28 weken zwan- 
gerschap hoorde Nederland in 2004 niet tot de landen met een hoog neonataal sterftecijfer, maar wel tot de landen met een hoog foetaal sterftecijfer, waarbij circa $45 \%$ van de sterfte plaatsvond bij 37+ weken (a term). ${ }^{7}$

\section{DETERMINANTEN VAN}

\section{PERINATALE STERFTE}

Verschillende determinanten zijn in meerdere of mindere mate van invloed op de perinatale sterfte. Er zijn karakteristieken van de pasgeborene (vroeggeboorte, laag geboortegewicht, intrauteriene groeivertraging, aangeboren afwijkingen, meerlingstatus) en karakteristieken van de moeder (leeftijd, pariteit, medische voorgeschiedenis, etniciteit, sociaal economische status, woonplaats, werkstress, persoonlijke en leefstijlfactoren zoals overgewicht, voeding en roken) die van invloed zijn op de kans op perinatale sterfte. Verder hebben ook het verloskundige zorgsysteem en de organisatie van de verloskundige en neonatale zorg invloed op de perinatale sterfte.

Vroeggeboorte, laag geboortegewicht en aangeboren afwijkingen verklaren samen $82 \%$ van de perinatale sterfte, ${ }^{8}$ en worden op hun beurt weer door andere factoren beïnvloed (bijvoorbeeld door roken tijdens de zwangerschap).

In dit artikel wordt een overzicht gegeven van de trend in belangrijke determinanten van perinatale sterfte, waarvoor op populatieniveau informatie voor handen is.
Dit overzicht baseert zich op data van de Stichting Perinatale Registratie Nederland ${ }^{9}$ en het Centraal Bureau voor de Statistiek. ${ }^{10}$ Daarnaast is gebruik gemaakt van recente nationale en internationale literatuur over (determinanten van ) perinatale sterfte in Nederland, waaronder ook bevindingen uit de longitudinale kindercohort studies ABCD in Amsterdam en Generation $\mathrm{R}$ in Rotterdam.

\section{TRENDS IN DETERMINANTEN PERINATALE STERFTE}

\section{Karakteristieken van de pasgeborene}

\section{Vroeggeboorte}

Vroeggeboorte is geassocieerd met ongunstige perinatale uitkomsten waaronder een hoge perinatale sterfte. Sinds 2004 is het percentage vroeg geborenen $(<37+0$ weken $)$ redelijk stabiel, namelijk rond de $7,7 \%$ (tabel 1$)$. Het percentage zeer vroeg geborenen $(<32+0$ weken) ligt rond de $1,5 \%$.

De perinatale sterfte is zeer hoog bij geboortes tussen de $22+0$ en $27+6$ weken zwangerschap; sterk verhoogd bij $28+0-31+6$ weken en verhoogd bij 32 tot 37 weken . De perinatale sterfte is in alle groepen sinds 2004 verminderd (tabel 2). Verbetering in de kwaliteit en organisatie van de

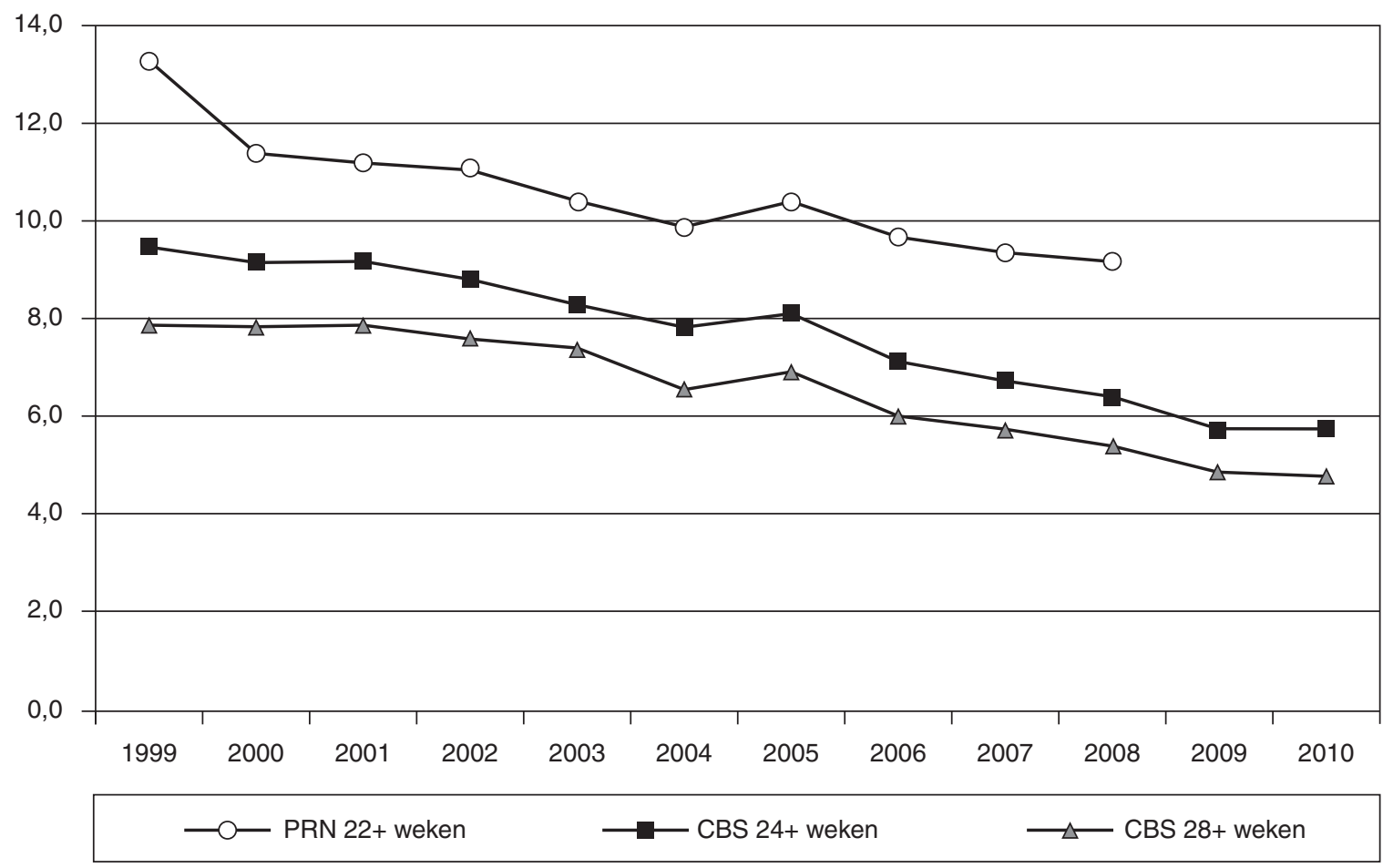


zorg zoals centralisatie van zorg voor hoog risico zwangerschappen, actieve behandeling bij geboorte, het antenataal toedienen van corticosteroïden en na de geboorte toediening van surfactant hebben hieraan bijgedragen.

\section{Laag geboortegewicht}

Ongeveer 6,6\% van de geborenen wordt geboren met een laag geboortegewicht (<2500 gram); 1,4\% van de geborenen is lichter dan 1500 gram. De perinatale sterfte in deze groepen is hoger en neemt exponentieel toe naarmate het kind eerder of lichter geboren wordt. Van alle baby's die vóór, tijdens of kort na de geboorte overlijden heeft ongeveer $40 \%$ een te laag geboortegewicht al dan niet gepaard met een andere risicofactor.

\section{Aangeboren afwijkingen}

Ongeveer 2,3\% van alle pasgeborenen in Nederland heeft één of meerdere aangeboren afwijkingen. ${ }^{7}$ Een deel van deze afwijkingen is gerelateerd aan een verhoogde kans op perinatale morbiditeit en mortaliteit. ${ }^{4,12}$ Zo heeft een pasgeborene met een neuraalbuisdefect ruim 50 keer verhoogd risico op sterfte in de perinatale periode en leidt een chromosomale afwijking tot een 20 keer verhoogde kans op perinatale sterfte. ${ }^{12}$

Lange tijd vond in Nederland in vergelijking met andere Europese landen nauwelijks prenatale screening plaats. ${ }^{5}$ Vanaf 2005 is geleidelijk het gebruik van echoscopie tijdens de zwangerschap toegenomen en op 1 januari 2007 is landelijk de zogenaamde 20 -weken echo ingevoerd. Hiermee kunnen ernstige aangeboren afwijkingen vroegtijdig ontdekt worden en kunnen ouders besluiten om de zwangerschap af te breken vóór 24 weken. Dergelijke ingrepen op medische indicatie vinden plaats in ziekenhuizen. De landelijke rapportages Wet Afbreking Zwangerschap laten zien dat het aandeel van ziekenhuizen in tweede trimester zwangerschapsafbrekingen vanaf het jaar 2004 geleidelijk aan is toegenomen van $5,2 \%$ naar $10,8 \%$ in $2009 .{ }^{13}$ In absolute aantallen betreft het een ruime verdubbeling van het aantal zwangerschapsafbrekingen op medische indicatie (262 in 2004 vs. 595 in 2010). Ook uit de rapportage Aangeboren Afwijkingen 1997-2007, een jaarlijkse monitor van de pre-

Tabel 1 Determinanten van perinatale sterfte in Nederland

\begin{tabular}{|c|c|c|c|c|c|c|c|c|c|c|c|c|c|}
\hline & Bron & Maat & 2000 & 2001 & 2002 & 2003 & 2004 & 2005 & 2006 & 2007 & 2008 & 2009 & 2010 \\
\hline \multirow{2}{*}{$\begin{array}{l}\text { Leeftijd moeder } \\
\text { (gemiddeld) }\end{array}$} & CBS & Jaar & 30,7 & 30,8 & 30,9 & 31,0 & 31,0 & 31,1 & 31,1 & 31,1 & 31,1 & 31,0 & 31,0 \\
\hline & PRN & Jaar & 30,7 & 30,8 & 30,8 & 30,9 & 31,0 & 31,1 & 31,1 & 31,1 & 31,0 & & \\
\hline \multicolumn{14}{|l|}{ Vroeggeboorte } \\
\hline$<32+0$ weken & PRN & $\%$ & 1,4 & 1,5 & 1,4 & 1,4 & 1,4 & 1,5 & 1,4 & 1,4 & 1,5 & & \\
\hline$<37+0$ weken & PRN & $\%$ & 8,0 & 7,9 & 7,7 & 7,6 & 7,7 & 7,7 & 7,7 & 7,5 & 7,7 & & \\
\hline Geboortegewicht & PRN & $\%$ & & & & & & & & & & & \\
\hline$<1500$ gram & & & 1,5 & 1,5 & 1,4 & 1,4 & 1,3 & 1,4 & 1,3 & 1,4 & 1,4 & & \\
\hline 1500-2499 gram & & & 5,9 & 5,8 & 5,6 & 5,5 & 5,5 & 5,4 & 5,4 & 5,2 & 5,2 & & \\
\hline 2500-3499 gram & & & 46,8 & 46,9 & 46,6 & 46,2 & 45,8 & 45,7 & 46,1 & 46,0 & 45,5 & & \\
\hline 3500-3999 gram & & & 31,0 & 31,1 & 31,5 & 31,6 & 31,7 & 31,8 & 31,7 & 31,9 & 32,1 & & \\
\hline 4000-4499 gram & & & 12,1 & 12,1 & 12,3 & 12,5 & 12,7 & 12,8 & 12,7 & 12,7 & 12,9 & & \\
\hline$\geq 4500$ gram & & & 2,5 & 2,5 & 2,5 & 2,7 & 2,9 & 2,8 & 2,7 & 2,8 & 2,7 & & \\
\hline \multirow{2}{*}{ Meerling } & PRN & $\%$ & 2,0 & 2,1 & 2,1 & 2,0 & 2,0 & 2,0 & 1,9 & 1,9 & 1,9 & & \\
\hline & CBS & $\%$ & 1,8 & 1,9 & 1,9 & 1,9 & 1,9 & 1,9 & 1,8 & 1,7 & 1,8 & 1,8 & 1,7 \\
\hline Leeftijd moeder & CBS & & & & & & & & & & & & \\
\hline$<20$ jaar & & $\%$ & 1,2 & 1,3 & 1,3 & 1,2 & 1,1 & 1,1 & 1,0 & 1,0 & 1,0 & 1,1 & 1,0 \\
\hline 20 tot 25 jaar & & $\%$ & 8,4 & 8,6 & 8,7 & 8,8 & 9,0 & 8,9 & 8,8 & 9,0 & 8,8 & 8,9 & 8,9 \\
\hline 25 tot 30 jaar & & $\%$ & 27,8 & 26,6 & 25,7 & 25,5 & 25,4 & 26,0 & 26,7 & 26,9 & 27,5 & 27,8 & 28,0 \\
\hline 30 tot 35 jaar & & $\%$ & 42,2 & 42,3 & 42,6 & 41,7 & 40,7 & 39,3 & 38,4 & 37,4 & 37,4 & 37,2 & 37,7 \\
\hline 35 tot 40 jaar & & $\%$ & 17,8 & 18,4 & 18,7 & 19,7 & 20,4 & 21,3 & 21,6 & 21,9 & 21,4 & 20,9 & 20,2 \\
\hline$\geq 40$ jaar & & $\%$ & 2,6 & 2,8 & 2,9 & 3,0 & 3,3 & 3,5 & 3,5 & 3,7 & 3,9 & 4,1 & 4,3 \\
\hline Pariteit & PRN & & & & & & & & & & & & \\
\hline Po & & $\%$ & 47,2 & 47,1 & 46,6 & 46,2 & 46,2 & 45,5 & 45,1 & 45,5 & 45,4 & & \\
\hline $\mathrm{P}_{1}$ & & $\%$ & 34,9 & 35,2 & 35,6 & 35,9 & 35,9 & 36,4 & 36,6 & 36,3 & 36,3 & & \\
\hline $\mathrm{P}_{2+}$ & & $\%$ & 17,9 & 17,7 & 17,8 & 17,9 & 17,9 & 18,1 & 18,3 & 18,2 & 18,3 & & \\
\hline \multicolumn{14}{|l|}{ Afkomst } \\
\hline $\begin{array}{l}\text { Niet-Westers } \\
\text { allochtonen }\end{array}$ & CBS & $\%$ & 14,7 & 15,3 & 15,5 & 15,7 & 16,4 & 16,8 & 17,0 & 17,2 & 17,1 & 17,2 & 17,7 \\
\hline Marokko & & & 24,1 & 23,7 & 24,2 & 24,9 & 25,6 & 26,2 & 26,0 & 25,4 & 25,2 & 24,7 & 24,0 \\
\hline Turkije & & & 22,7 & 21,7 & 21,0 & 20,6 & 20,3 & 20,8 & 20,2 & 20,0 & 19,3 & 18,5 & 18,6 \\
\hline Nederlandse & & & 6,3 & 6,7 & 6,8 & 6,7 & 6,6 & 6,3 & 6,4 & 6,7 & 7,1 & 7,0 & 6,8 \\
\hline \multicolumn{14}{|l|}{ Antillen en Aruba } \\
\hline Suriname & & & 15,9 & 16,1 & 15,6 & 15,1 & 14,7 & 14,4 & 14,6 & 14,9 & 15,2 & 15,4 & 15,2 \\
\hline $\begin{array}{l}\text { Aangeboren } \\
\text { afwijkingen } \\
\text { Neuraal buis- } \\
\text { defecten }\end{array}$ & TNO & $\begin{array}{l}\text { per } 10.000 \\
\text { geborenen }\end{array}$ & & & & & & & & & & & \\
\hline Anencefalie & & & 2,8 & 2,4 & 3,3 & 2,4 & 1,4 & 2,3 & 1,6 & 1,8 & 1,8 & 1,3 & \\
\hline Spina bifida & & & 6,3 & 5,8 & 5,2 & 4,6 & 4,7 & 5,4 & 5,6 & 5,6 & 5,7 & 5,6 & \\
\hline
\end{tabular}


Tabel 2 Perinatale sterfte per 1000 geborenen (bron CBS ${ }^{10}$ )

\begin{tabular}{|c|c|c|c|c|c|}
\hline Kenmerken & 2004 & 2005 & 2006 & 2007 & 2008 \\
\hline \multicolumn{6}{|l|}{ Zwangerschapsduur 22+o weken of meer } \\
\hline $22+0-27+6$ weken & 678,1 & 730,9 & 696,3 & 693,9 & 659,6 \\
\hline $28+0-31+6$ weken & 146,6 & 133,0 & 144,1 & 128,1 & 102,2 \\
\hline $32+0-36+6$ weken & 27,9 & 29,0 & 22,3 & 20,7 & 20,2 \\
\hline $\begin{array}{l}37+0 \text { weken of meer } \\
\text { Geboortegewicht }\end{array}$ & 2,9 & 3,1 & 2,8 & 2,6 & 2,5 \\
\hline Niet licht voor zwangerschapsduur $(\mathrm{p} \geq 10)$ & 1,5 & 1,4 & 1,4 & 1,4 & 1 \\
\hline Licht voor zwangerschapsduur $(\mathrm{p}<10)$ & 4,7 & 5,9 & 3,9 & 2,7 & 3,1 \\
\hline Eenlingen en meerlingen & 9,2 & 9,8 & 9,1 & 8,9 & 8,6 \\
\hline Eenlingen & 8,2 & 8,7 & 8,2 & 8,1 & 7,9 \\
\hline Meerlingen & 33,3 & 40,3 & 32,2 & 32,2 & 28,3 \\
\hline \multicolumn{6}{|l|}{ Leeftijd moeder } \\
\hline Jonger dan 20 jaar & 8,2 & 10,7 & 17,2 & 17,0 & 12,0 \\
\hline 20 tot 25 jaar & 10,9 & 11,1 & 11,0 & 9,3 & 8,7 \\
\hline 25 tot 30 jaar & 8,5 & 9,0 & 8,8 & 7,7 & 8,2 \\
\hline 30 tot 35 jaar & 8,2 & 8,9 & 7,6 & 8,3 & 8,0 \\
\hline 35 tot 40 jaar & 10,4 & 11,6 & 9,7 & 10,3 & 9,1 \\
\hline 40 jaar of ouder & 15,7 & 15,9 & 16,1 & 14,1 & 17,0 \\
\hline \multicolumn{6}{|l|}{ Pariteit } \\
\hline Para 1 & 10,5 & 10,8 & 10,8 & 9,8 & 9,9 \\
\hline Para 2 & 6,8 & 8,3 & 6,9 & 7,5 & 6,7 \\
\hline Para 3 & 8,6 & 9,4 & 8,2 & 7,7 & 8,0 \\
\hline Para 4 of meer & 14,6 & 13,6 & 11,8 & 14,5 & 13,2 \\
\hline \multicolumn{6}{|l|}{ Afkomst } \\
\hline Nederlands & 8,6 & 9,1 & 8,3 & 8,4 & 8,0 \\
\hline Niet westerse allochtonen, 1e generatie & 12,8 & 14,3 & 11,7 & 11,9 & 12,7 \\
\hline Niet westerse allochtonen, ze generatie & 11,4 & 12,1 & 11,0 & 9,6 & 11,6 \\
\hline Niet-westerse allochtoon & 12,6 & 13,9 & 11,5 & 11,4 & 12,4 \\
\hline Marokko & 12,5 & 13,5 & 10,5 & 9,2 & 10,6 \\
\hline Turkije & 9,1 & 9,7 & 9,4 & 9,3 & 11,5 \\
\hline Suriname & 16,5 & 16,1 & 13,5 & 11,2 & 15,1 \\
\hline Nederlandse Antillen en Aruba & 16,4 & 17,5 & 17,4 & 16,4 & 14,1 \\
\hline Overige niet-westers & 12,1 & 15,3 & 11,6 & 13,3 & 12,6 \\
\hline \multicolumn{6}{|l|}{ Inkomensgroep } \\
\hline $1^{\text {ste }} 20 \%$-inkomensgroep & 12,1 & 11,8 & 12,2 & 11,4 & 11,5 \\
\hline $2^{\text {de }} 20 \%$-inkomensgroep & 8,5 & 9,6 & 8,6 & 8,3 & 8,6 \\
\hline $3^{\text {de }} 20 \%$-inkomensgroep & 8,6 & 9,9 & 8,7 & 9,4 & 8 \\
\hline $4^{\text {de }} 20 \%$-inkomensgroep & 9,1 & 9,4 & 8 & 7,9 & 9 \\
\hline $5^{\text {de }} 20 \%$-inkomensgroep & 7,5 & 8,5 & 7,8 & 7,6 & 6,4 \\
\hline
\end{tabular}

valentie Aangeboren Afwijkingen in Nederland is vanaf 2005 een toename in het aantal meldingen van spina bifida en hydrocefalie rond 20 weken zwangerschap te zien. ${ }^{14}$ Dit is een eerste aanwijzing van het effect van vroegtijdige opsporing voor ernstige aangeboren afwijkingen. Zwangerschapsafbrekingen vóór 22 weken zwangerschap worden niet opgenomen bij internationale vergelijking van perinatale sterftestatistieken. Ook bij een gelijkblijvende prevalentie van ernstige aangeboren afwijkingen zal daardoor de perinatale sterfte iets dalen.

Naast toegenomen prenatale diagnostiek kunnen ook veranderingen in leefstijl de prevalentie van aangeboren afwijkingen beïnvloeden (primaire preventie). Een voorbeeld hiervan is het gebruik van foliumzuur ter preventie van neuraalbuisdefecten. Door het gebruik van foliumzuur rond de conceptie neemt de kans op een kind met een neuraalbuisdefect met $70 \%$ af. ${ }^{15}$ Kort na de Nederlandse foliumzuurcampagne van 1995 was het gebruik van foliumzuur in de aanbevolen periode $21 \%$. ${ }^{16}$ Recent onderzoek geeft aan dat het gebruik in de aanbevolen periode in Noord-Nederland bijna 52\% is. ${ }^{17} \mathrm{Na} 1995$ was er een afname in de prevalentie van neuraalbuisdefecten waarneembaar die echter sinds 2004 lijkt te zijn gestabiliseerd. ${ }^{18}$ Het is aannemelijk dat deze afname gerelateerd is aan het gebruik van foliumzuur in Nederland.

\section{Meerlingzwangerschappen}

Het aantal in Nederland geboren kinderen dat deel van een meerling is, steeg vanaf 1990 gestaag van minder dan 6000 tot bijna 8000 per jaar. ${ }^{10}$ Rond 2000 stabiliseerde het percentage meerlingen, daarna daalde het gestaag. Het CBS rapporteert een percentage van 1,7\% in 2010 (tabel 1). Het percentage meerlingzwangerschappen hangt samen met een hogere leeftijd van de moeder en met fertiliteitsbehandelingen (hormoonstimulatie en terugplaatsing van meer dan één embryo bij IVF). Landelijke IVF-gegevens (vanaf 2003 beschikbaar) laten zien dat het aantal meerlingkinderen na een IVF-behandeling (inclusief ICSI e.d.) vanaf 2003 duidelijk gedaald is sinds er vaker voor gekozen wordt één in plaats van twee embryo's terug te plaatsen. ${ }^{10,19}$

Bij meerlingzwangerschappen is vaker sprake van vroeggeboorte en/of groeiachterstand waardoor de perinatale sterfte aanmerkelijk is verhoogd in vergelijking met eenlingen. (tabel 2). Het is aannemelijk dat genoemde verbeteringen in IVF-technologie en de keuze om vaker één eicel terug te plaatsen hebben bijgedragen aan de daling van de perinatale sterfte in de periode 2000 2010. Een grove schatting: 810 minder meerlingkinderen met een relatief risico van ongeveer 4 zorgde voor een geschatte verlaging van de sterfte met 25-30 gevallen. Indien de daling in percentage meerlingzwangerschappen 
doorzet heeft dit een gunstig effect op de perinatale sterfte.

\section{Maternale karakteristieken}

\section{Leeftijd moeder bij geboorte}

De afgelopen decennia fluctueert de gemiddelde leeftijd van de moeder rond 31 jaar $(30,7-31,1 \%)$. De afgelopen jaren is het percentage moeders in de leeftijdscategorie 30-35 jaar geleidelijk afgenomen van ongeveer $42 \%$ in de jaren 2000-2003 naar ongeveer 37\% in de jaren 20072010. Aan de andere kant wordt een toename gezien in het percentage moeders van 35 jaar of ouder (van ca. $20 \%$ in 2000 naar ca. $25 \%$ in de periode 2005-2010) (tabel 1).

De laagste perinatale sterftecijfers worden in Nederland gezien in de leeftijdscategorie 30-35 jaar $(8,0 \%$ ). De perinatale sterfte is het hoogst bij de jongste $(<20$ jaar $)$ en oudste ( $\geq 40$ jaar) moeders, respectievelijk 12,0 en 17,0\% (zie tabel 2).

Het percentage tienerzwangerschappen fluctueert in Nederland al langer rond 1,0\%. Alhoewel er in de periode 2000-2005 sprake leek te zijn van een lichte stijging is dit percentage in de periode na 2005 weer gedaald tot ongeveer $1,0 \%$. Tienerzwangerschappen komen veel vaker voor bij niet-Westers allochtone meisjes.

Het percentage vrouwen dat bevalt bij 40 jaar of ouder neemt nog steeds toe (tabel 1). In 2010 was 4,3\% van de vrouwen die bevallen 40 jaar of ouder. Dit is een stijging van $30 \%$ en $65 \%$ vergeleken met respectievelijk de jaren 2004 en 2000. Hoewel het risico op perinatale sterfte in deze groep verhoogd is en het aantal oudere moeders nog steeds stijgt zal het effect op de perinatale sterfte nog beperkt zijn door het relatief lage absolute aantal vrouwen in deze leeftijdsgroep.

\section{Pariteit}

Ruim $45 \%$ van de vrouwen is zwanger van hun eerste kind (tabel 1). Sinds 2000 is dit percentage iets afgenomen, van $47,2 \%$ naar $45,4 \%$ in 2008 . Het percentage vrouwen dat zwanger is van hun tweede kind is ongeveer $36 \%$. Vooral bij niet-Westerse allochtone vrouwen komen vaker hogere multipara voor.

Perinatale sterfte komt relatief vaker voor bij primiparae en bij vier of meer zwangerschappen (tabel 2). Sinds 2004 is er een lichte afname in de perinatale sterfte bij primiparae.

\section{Etniciteit}

Al langere tijd neemt in Nederland het aantal geborenen met een niet-Westers allochtone afkomst toe. ${ }^{6,20}$ In 2010 was $17,7 \%$ van de geborenen van niet-Westers allochtone afkomst ten opzichte van $14,7 \%$ in 2000 . Bijna $45 \%$ van deze geborenen zijn van Marokkaanse of Turkse afkomst; ongeveer $15 \%$ is van Surinaamse afkomst (tabel 1).

Het perinatale sterftecijfer bij geborenen van nietWesterse allochtone afkomst (12,4\% in 2008) is hoger dan bij geborenen van Nederlandse afkomst $(8,0 \%$ in 2008) (tabel 2). Er is nauwelijks verschil in perinatale sterfte tussen niet-Westerse vrouwen van de eerste of tweede generatie (12,7 versus $11,6 \%$ ). Onder niet-Wes- terse allochtonen wordt het hoogste sterftecijfer onder Surinamers waargenomen $(15,1 \% 0)$, gevolgd door de Nederlandse Antillianen en Arubanen (14,1\%). Maar ook onder Marokkanen en Turken is de perinatale sterfte hoog, respectievelijk 10,6\% en 11,5\%o in 2008.

\section{Woonplaats}

Er zijn verschillen in perinatale sterftecijfers tussen en binnen Nederlandse steden. ${ }^{21}$ Het perinatale sterftecijfer ligt hoger in de vier grote steden van Nederland vergeleken met de rest van Nederland (11,1 versus 9,3\%). Tussen de grote steden zijn er ook verschillen waarneembaar en ligt het sterftecijfer relatief hoger in Den Haag $(11,8 \% 0)$, Utrecht $(11,6 \%$ ), en Rotterdam $(11,4 \%$ ), dan in Amsterdam (10,1\%o). Uit het onderzoek van de Graaf blijkt ook dat onafhankelijk van de woonplaats perinatale sterftecijfers hoger liggen bij niet-Westerse (12,5-14,6\%) dan bij Westerse vrouwen $(7,7-11,1 \% 0)$. Binnen de grote steden blijken ook grote verschillen te bestaan, met veel hogere sterftecijfers in achterstandswijken.

Verschillen in perinatale sterfte zijn ook in Nederland sterk aan SES-verschillen gekoppeld. Vooral in de laagste inkomensgroep (1ste 20\%-inkomensgroep) wordt een verhoogde perinatale sterfte gezien. Deze was $11,5 \%$ in 2008 (tabel 2).

\section{Roken}

Het percentage vrouwen dat rookt tijdens de zwangerschap is in Nederland tussen 2001 en 2010 gehalveerd, maar nog steeds rookt 6,3\% van alle zwangeren in $\mathrm{Ne}$ derland. Laagopgeleide zwangeren roken zes keer zo vaak als hoogopgeleide zwangeren, middelbaar opgeleide zwangeren roken drie keer zo vaak als hoogopgeleide zwangeren. Bij deze dalende trend zijn absolute verschillen in rookprevalenties tussen de opleidingsniveaus in het afgelopen decennium onveranderd gebleven. ${ }^{22}$ De ABCD studie uitgevoerd in 2003 laat zien dat in 2003 met name Turkse vrouwen (16,9\%) en Nederlandse vrouwen $(11,2 \%)$ relatief vaker rookten tijdens de zwangerschap. ${ }^{23}$

Roken tijdens de zwangerschap geeft onder andere een verhoogd risico op vroeggeboorte, groeivertraging, en perinatale sterfte. ${ }^{24}$ Dit geldt óók wanneer weinig wordt gerookt (bijvoorbeeld na minderen met roken) en voor passief roken. Zo kan naar schatting $29 \%$ van de vroeggeboortes en $17 \%$ van de intra-uteriene groeivertraging per jaar vermeden worden als geen van de zwangere vrouwen zou roken tijdens de zwangerschap. ${ }^{24}$

De dalende trend in rookprevalentie bij zwangere vrouwen in Nederland heeft waarschijnlijk dan ook bijgedragen aan de dalende perinatale sterftetrend.

\section{Obesitas}

Net als in andere westerse landen neemt de prevalentie van overgewicht en obesitas (ernstig overgewicht) in Nederland sterk toe. In 2010 was er bij 41,2\% van de vrouwen in de leeftijdsgroep 30-40 jaar sprake van overgewicht. In deze leeftijdsgroep was er bij 12,4\% van de vrouwen sprake van obesitas. ${ }^{10}$

Op landelijke niveau zijn er geen gegevens over het 
vóórkomen van overgewicht bij zwangere vrouwen bekend. Wel zijn er gegevens beschikbaar uit twee populatiestudies onder zwangere vrouwen. In Amsterdam was in 2003 in $23,6 \%$ van de populatie zwangere vrouwen sprake van overgewicht (17,3\% overgewicht en 6,3\% ernstig overgewicht). ${ }^{23}$ Van zwangere vrouwen die deelnamen aan de Generation R studie was er bij 27,6\% van de vrouwen sprake van overgewicht. ${ }^{25}$

Ook werden aanmerkelijke verschillen in de prevalentie van obesitas gevonden tussen bevolkingsgroepen in Nederland. De prevalentie van overgewicht onder $\mathrm{Ne}-$ derlandse en Westerse vrouwen was het laagst, respectievelijk $17,8 \%$ en $14,6 \%$. De prevalentie van overgewicht onder Marokkaanse vrouwen was het hoogst met 51,1\% gevolgd door Afrikaanse vrouwen met $48,9 \%$ en Turkse vrouwen met $33,7 \%$. Het is aannemelijk dat het percentage zwangere vrouwen met overgewicht en obesitas de laatste jaren verder is toegenomen.

Overgewicht en obesitas zijn geassocieerd met een verhoogd risico op zwangerschapscomplicaties en perinatale sterfte. Obesitas gaat gepaard met een verdubbelde kans op doodgeboorte. ${ }^{26}$ Obesitas is ook geassocieerd met een verhoogd risico op diabetes, wat weer een risicofactor is voor perinatale complicaties, aangeboren afwijkingen en perinatale sterfte. Djelantik vond dat obesitas in belangrijke mate bijdraagt aan het optreden van ongunstige zwangerschapsuitkomsten (vroeggeboorte en groeiachterstand) die op zichzelf een verhoogd risico op perinatale sterfte met zich meebrengen. ${ }^{23}$ Ook werden verhoogd risico op hoge bloeddruk tijdens de zwangerschap en preeclampsie gevonden. ${ }^{25}$ Hierdoor is het aannemelijk dat de toenemende trend in obesitas een ongunstig effect heeft op de trend in perinatale sterfte.

\section{BESCHOUWING}

In Nederland is de perinatale sterfte de afgelopen jaren verder gedaald. Daarachter ligt een complex, interacterend samenspel van gunstige en ongunstige ontwikkelingen in determinanten die samen de hoogte van de perinatale sterfte bepalen. Vroeggeboorte, laag geboortegewicht en aangeboren afwijkingen verklaren gezamenlijk $82 \%$ van de perinatale sterfte. Het voorkomen van deze determinanten wordt deels beïnvloed door determinanten die op zichzelf ook het risico op perinatale sterfte verhogen. Aan de ene kant zijn er ontwikkelingen in de prevalentie van determinanten die een gunstige invloed hebben op de prevalentie van vroeggeboorte, zoals een lager aantal meerlingen door veranderd beleid rond IVF, en een lager aantal zwangeren dat rookt. Maar er zijn ook ongunstige ontwikkelingen zoals een stijgende prevalentie van (ernstig) overgewicht tijdens de zwangerschap en blijvend licht toenemend aantal niet-Nederlandse zwangeren. Daarnaast dragen ontwikkelingen in de zorg bij aan het voorkomen van perinatale sterfte. Zo is de sterfte bij vroeggeboorte tussen 28-32 weken en 32-36 weken de afgelopen periode merkbaar gedaald, mede door concentratie van zorg voor hoog risico zwangerschappen, actief management bij de bevalling, antenataal toedienen van steroïden en postnataal toedienen van surfactant.

Naast bovengenoemde ontwikkeling zijn er verande- ringen in beleid en veranderingen in de populatie die van invloed zijn op de trend in perinatale sterfte. Zo zijn er veranderingen in het beleid rond vroegtijdige opsporing van ernstige aangeboren afwijkingen. Hierdoor worden getroffen zwangerschappen vaker afgebroken vóór 22 weken en voorkomt dat gevallen van perinatale sterfte. Het betekent echter niet dat de prevalentie van ernstige aangeboren afwijkingen is gedaald.

Het toenemend percentage zwangere vrouwen van 35 jaar of ouder is niet gunstig voor de trend in perinatale sterfte, maar de invloed hiervan op de totale perinatale sterfte is waarschijnlijk niet zo groot op populatieniveau.

Ook het nog, weliswaar licht, toenemend aandeel van zwangerschappen bij niet-westerse allochtone vrouwen vertraagt de daling van de perinatale sterfte. De sterfte in deze groepen is nog verhoogd voor vrouwen van zowel de eerste als de tweede generatie.

$\mathrm{Er}$ is ook een verhoogde perinatale sterfte waarneembaar in de grote steden en in achterstandswijken van grote steden die onafhankelijk is van het land van herkomst van de zwangere vrouw. Daarachter ligt een bundeling van risicofactoren waarbij minder goede sociale omstandigheden een rol spelen die geassocieerd zijn met een verhoogde kans op perinatale sterfte.

Ook leefstijlfactoren spelen een rol bij het risico op perinatale sterfte. Optimaliseren van leefstijlfactoren door middel van preventie kan de trend in perinatale sterfte gunstig beïnvloeden. Gunstig is de recent ingezette daling in het percentage vrouwen dat rookt tijdens de zwangerschap. Deze daling wordt ook gezien bij vrouwen met een laag opleidingsniveau, al roken nog steeds (veel) meer vrouwen met een laag opleidingsniveau tijdens de zwangerschap dan hoog opgeleide vrouwen. Vanwege het verhoogd risico op vroeggeboorte en groeiachterstand door roken in de zwangerschap is dit een gunstige ontwikkeling.

Ongunstig is de toename van zwangere vrouwen met (ernstig) overgewicht, aangezien hiermee de kans op vroeggeboorte, laag geboortegewicht en dus ook perinatale sterfte toeneemt. Preventie van overgewicht zal daarom bijdragen aan een vermindering van de perinatale sterfte.

Naast bovengenoemde factoren hebben ook het verloskundige zorgsysteem en de organisatie van de verloskundige en neonatale zorg invloed op de hoogte van de perinatale sterfte. Het optimaliseren van de geboortezorg heeft in Nederland al geruime tijd de aandacht van zorgverleners en van beleidsmakers. De afgelopen jaren zijn er vele initiatieven gestart die hierop gericht zijn, zoals bijvoorbeeld de perinatale audit en het naar aanleiding van het Stuurgroep advies 'Een goed begin' ${ }^{27}$ in 2011 opgerichte College Perinatale Zorg. Tevens zijn door het Ministerie middelen beschikbaar gesteld aan ZonMw voor het onderzoeksprogramma Zwangerschap en Geboorte.

Gezien de relatie tussen leefstijlfactoren, niet optimale leefomstandigheden en ongunstige zwangerschapsuitkomsten is het belangrijk dat naast medisch ingestoken oplossingen en integrale zorg ook naar andere manieren wordt gezocht om de gezondheid van toekomstige ouders en pasgeborenen te bevorderen. Een voorbeeld is vrou- 
wen en hun partner ter voorbereiding op een zwangerschap een consult aan te bieden (preconceptiezorg). Hierdoor is het mogelijk om op basis van een anamnese tijdig bijvoorbeeld medicatie, werkomstandigheden en leefstijlfactoren aan te passen. Daartoe lopen verschillende initiatieven op dit terrein. In het programma Healthy Pregnancy 4 All dat momenteel in 14 gemeenten in Nederland wordt ingevoerd ${ }^{28}$ wordt bijvoorbeeld via risicoselectie specifieke zorg aangeboden ter bevordering van een gunstige zwangerschapsuitkomst. Een ander model voor bevordering van een gunstige zwangerschapsuitkomst is het aanbieden van prenatale zorg in groepen, CenteringPregnancy. De zwangere vrouw staat in dit model van zorg centraal. Tijdens de groepsbijeenkomst wordt de medische controle gecombineerd met voorlichting en het stimuleren van support en zelfredzaamheid onder zwangeren. Deze methode is in Amerika effectief gebleken onder andere in het verminderen van vroeggeboorte. $^{29}$

\section{CONCLUSIE}

Perinatale sterfte wordt beïnvloed door een groot aantal, complex interacterende determinanten. Recente ontwikkelingen in de perinatale zorg gericht op het optimaliseren van de perinatale gezondheid en verminderen van de perinatale sterfte hebben reeds een positief effect gehad op enkele van deze determinanten. Daarnaast kunnen andere factoren verder beïnvloed worden door preventieve maatregelen. Uit lopend onderzoek op het gebied van preconceptiezorg en prenatale zorg zal kunnen blijken welke interventies kunnen bijdragen aan een verdere daling van de perinatale sterfte in Nederland.

\section{ABSTRACT \\ Trends in determinants of perinatal death in the Nether- lands}

Perinatal death is een important indicator of quality of care. The trend in perinatal death is influenced by is a large set of interacting determinants. Maternal characteristics (such as medical history, life style and social circumstances), neonatal characteristics (preterm birth, small for gestational age, congenital malformations) and characteristics related to care play a role. In the Netherlands the prevalence of perinatal death decreased further during the last years. This does not mean that the trend in all determinants is also decreasing. Determinants that have improved are the survival of preterm birth and the number of women smoking during pregnancy. On the other hand we see an increase in the number of obese women, and the still slightly increasing prevalence of pregnancies among women of 35 years and older, and among non-western migrant women. Besides medical solution and integration of care, primary prevention before and during pregnancy to improve the health of parents (to be) and their baby's is important because of the relation between life style, suboptimal social circumstances and adverse pregnancy outcome. tion

Keywords: trend, determinants perinatal death, preven-

\section{LITERATUUR}

1. Richardus JH, Graafmans WC, Verloove-Vanhorick SP, et al. Differences in perinatal mortality and suboptimal care between 10 European regions: results of an international audit. BJOG 2003;110:97-105.

2. EPHR (European Perinatal Health Report). EURO-PERISTAT Project, 2008. www.europeristat.com

3. Buitendijk SE, Nijhuis JG. Hoge perinatale sterfte in Nederland in vergelijking tot de rest van Europa. Ned Tijdschr Geneeskd 2004;148:1855-60.

4. Mohangoo AD, Buitendijk SE, Hukkelhoven CWPM et al. Hoge perinatale sterfte in Nederland vergeleken met andere Europese landen. De PERISTAT II Studie. Ned Tijdschr Geneeskd 2008;152:2718-27.

5. Garne E, Khoshnood B, Loane M, Boyd P, Dolk H. Termination of pregnancy for fetal anomaly after 23 weeks of gestation: a European register-based study. BJOG 2010;117:660-6.

6. Achterberg PW, Kramers PGN. Een gezonde start? Sterfte rond de geboorte in Nederland: trends en oorzaken vanuit internationaal perspectief. Bilthoven: RIVM, 2001.

7. Mohangoo AD, Buitendijk SE, Szamotulska K et al. Gestational age patterns of fetal and neonatal mortality in Europe: results from the Euro-Peristat project. PLoS One 2011;6(11):e24727.

8. Bonsel GJ, Birnie E, Denktas S, Poeran J, STeegers EAP. Lijnen in de Perinatale Sterfte, Signalementstudie Zwangerschap en Geboorte 2010. Rotterdam: Erasmus MC, 2010.

9. Stichting Perinatale Registratie Nederland. Grote Lijnen 10 jaar Perinatale Registratie Nederland. Utrecht: PRN, 2011.

10. http://statline.cbs.nl

11. Pal-de Bruin KM van der, Graafmans W, Richardus JH et al. The influence of prenatal screening and termination of pregnancy on perinatal mortality rates. Prenat Diagn 2002;22:966-72.

12. Mohangoo AD, Anthony S, Detmar SD, Buitendijk SE. Aangeboren afwijkingen in Nederland 1996-2006. Gebaseerd op de landelijke verloskunde en neonatologie registraties. Leiden: TNO, 2008.

13. IGZ. Jaarrapportage 2010 van de Wet afbreking zwangerschap. Den Haag: IGZ, 2011.

14. Mohangoo AD, Buitendijk SE. Aangeboren afwijkingen in Nederland 1996-2007. Gebaseerd op de landelijke verloskunde en neonatologie registraties. Leiden: TNO, 2009.

15. MRC Vitamin Study Research Group. Prevention. Prevention of neural tube defects by perinconceptional vitamin supplementation. Lancet 1991;338:131-7.

16. Pal-de Bruin KM van der, Walle HEK de, Jeeninga $W$ et al. The Dutch 'Folic Acid Campaign' have the goals been achieved? Pediatrics Perinat Epidemiol 2000;14:111-7.

17. Woude PA, Walle HEK de, Berg LT. Periconceptional folic acid use: still room to improve. Birth Defects Res A Clin Mol Teratol 2012;94:96-101.

18. Mohangoo AD, Pal-de Bruin KM van der, Buitendijk SE. Aangeboren afwijkingen in Nederland 1996-2008. Gebaseerd op de landelijke verloskunde en neonatologie registraties. Leiden: TNO, 2010

19. Smeenk J, Kremer J. Landelijke IVF-cijfers 1996-2010. Utrecht: NVOG, 2011

20. Garssen J, Meulen A van der. Ontwikkelingen rond perinatale sterfte in Nederland. CBS Bevolkingstrends 2004;52(3):15-31.

21. Graaf JP de, Ravelli ACJ, Wildschut HIJ et al. Perinatale uit- 
komsten in de vier grote steden en de prachtwijken in Nederland. Ned Tijdschr Geneeskd 2008;152:2734-40.

22. Lanting CI, Wouwe JP van, Burg I van den, Segaar D, Pal-de Bruin KM van der. Roken in de zwangerschap 2001 - 2010: Zwangeren roken steeds minder, maar verschillen tussen laag en hoogopgeleiden blijven onveranderd groot. Ned Tijdschr Geneeskd (in druk).

23. Djelantik A, Kunst A, Wal $M$ van der, Smit H, Vrijkotte T. Contribution of overweight and obesity to the occurrence of adverse pregnancy outcomes in al multi-ethnic cohort: population attributive fractions for Amsterdam. BJOG 2012;19:28390.

24. Lanting CI, Buitendijk SE, Crone MR et al. Clustering of Socioeconomic, Behavioural, and Neonatal Risk Factors for Infant Health in Pregnant Smokers. PLoS One 2009;4(12):e8386.

25. Gaillard R, Steegers EAP, Hofman A, Jaddoe VWV. Associations of maternal obesity with blood pressure and the risks of gestational hypertensive disorders. The Generation R Study. J Hypertens 2011;29:937-44.
26. Cnattingius S, Lambe $M$. Trends in smoking and overweight during pregnancy: prevalence, risks of pregnancy complications and adverse pregnancy outcomes. Semin Perinatology 2002:26;286-95.

27. Stuurgroep zwangerschap en geboorte. Een goed begin. Veilige zorg rond zwangerschap en geboorte. Utrecht: Stuurgroep zwangerschap en geboorte, 2009.

28. DenktaşS, Bonsel GJ, Steegers EAP. Perinatale gezondheid in Rotterdam. Ervaringen na 2 jaar 'Klaar voor een kind. Ned Tijdschr Geneeskd 2012;156:A4289.

29. Ickovics JR, Kershaw TS, Westdahl C et al. Group Prenatal Care and Perinatal Outcomes, A Randomized Controlled Trial. Obstet Gynecol 2007;110:330-9.

\section{CORRESPONDENTIEADRES}

Dr. KM van der Pal-de Bruin, Postbus 2215, 2301 CE Leiden, tel. 088-8662429,

e-mail: karin.vanderpal@tno.nl 